\title{
Strategi Membangun Branding Usaha Ekspor Briket Arang Tempurung Kelapa Pada UKM "Briqeo"
}

\author{
Retno Wulandari1*, Diyah Candra Anita ${ }^{2}$, dan Hendrato Setiabudi Nugroho ${ }^{3}$ \\ 1. UMY, Jl. Brawijaya, Geblagan, Tamantirto, Kec. Kasihan, Yogyakarta, Daerah Istimewa Yogyakarta 55183 (082134193475) \\ ${ }^{2}$ UNISA, Mlangi Nogotirto, Jl. Siliwangi Jl. Ringroad Barat No.63, Area Sawah, Nogotirto, Kec. Gamping, Kabupaten Sleman, Daerah \\ Istimewa Yogyakarta 55592 \\ ${ }^{3}$ UNISA, Mlangi Nogotirto, Jl. Siliwangi Jl. Ringroad Barat No.63, Area Sawah, Nogotirto, Kec. Gamping, Kabupaten Sleman, Daerah \\ Istimewa Yogyakarta 55592 \\ Email: retnowulandaria8@gmail.com \\ DOI: $10.18196 / \mathrm{ppm} .31 .138$
}

\begin{abstract}
Abstrak
Strategi Global Value Chain digunakan untuk menghadapi persaingan pasar global, sehingga UMKM mampu beradaptasi di pasar global. Tujuan yang ingin dicapai dalam program PPUD (Pengembangan Produk Unggulan Daerah) pada tahun ketiga ini, antara lain: penyelenggaraan Workshop Global Value Chain dan seluk-beluk ekspor impor, pembuatan aspek legalitas CV, pengurusan merk dagang BriqCo, pengurusan Izin Gangguan (IG), peningkatan branding melalui pembuatan website dan market place (Brand Awarness) serta penambahan mesin produksi. Metode yang dilakukan melalui rapat koordinasi, pelatihan dan simulasi, pembuatan alat dengan alih teknologi guna efisiensi produksi, pengurusan legalitas dan paten serta pembuatan website. Hasil implementasi yang dilakukan pada bulan Maret - Agustus 2020 antara lain tercapainya efisiensi produksi limbah briket arang tempurung kelapa sekaligus alih teknologi dengan membuat oven pengeringan dengan penambahan bowler, terbentuknya kesadaran diri tentang pentingnya pajak dan aspek legalitas usaha BriqCo, peningkatan branding usaha melalui pembuatan website perusahaan, telah tersedianya akta notaris perusahaan. Luaran dalam program pengabdian masyarakat ini adalah bertambahnya jumlah karyawan dari 38 orang menjadi 41 orang karyawan, owner meningkat pengetahuan perpajakan, efisiensi produksi limbah briket dengan produksi bara-bara, peningkatan branding dengan adanya website dan legalitas usaha CV serta persiapan relokasi pabrik.
\end{abstract}

Kata Kunci: briket arang, global value chain, upgrading, branding, legalitas usaha

\section{Pendahuluan}

Meski banyak tantangan, pasar global harus dihadapi oleh pengusaha Indonesia terutama UKM (Usaha Kecil \& Menengah). UKM sebenarnya mempunyai peluang untuk memperoleh keuntungan dari pasar global. Melalui strategi yang tepat dan benar, UKM di Indonesia dapat bersaing dengan UKM di negara-negara berkembang lainnya khususnya di Asia Tenggara untuk masuk dan diterima di pasar global (Arfani, 2013). Untuk itu diperlukannya sebuah metode yang tepat dan sistematis yang dapat digunakan oleh UKM untuk masuk dan bertahan di pasar global. Metode tersebut adalah Global Value Chain (GVC). Sebuah metode yang sudah diterapkan di pelbagai negara serta sudah terbukti keberhasilannya. Global Value Chain adalah cara yang mudah diterapkan untuk UKM sehingga ia dapat segera naik ke level yang lebih tinggi. Keberhasilan dari metode GVC ini dapat diterapkan ke UKM yang berorientasi pada ekspor (Stephenson, S. (2013; Downing, 2014).

Salah satu UKM yang sedang berkembang dan mempunyai peluang ekspor yang cukup besar di pasar global adalah briket arang tempurung kelapa. Permintaan akan briket arang mulai masuk ke Indonesia pada awal tahun 2000-an. Produk briket banyak dibutuhkan di Eropa, Amerika dan Timur Tengah. Di Eropa dan Amerika, briket arang tempurung kelapa dibutuhkan sebagai bahan bakar untuk barbeque. Sedangkan di Timur Tengah, briket arang digunakan sebagai bahan bakar untuk rokok sissa. Hal ini yang mendorong permintaan dari luar negeri sehingga memunculkan pengusaha-pengusaha briket arang batok kelapa (Gereffi \& FernandezStark, 2016).

UKM BriqCo mulai dirintis oleh Novi Setiawan sejak tahun 2009. Kapasitas produksi BriqCo saat ini mencapai maksimum 1,8 ton perhari. Rendahnya kapasitas produksi dari BriqCo 
disebabkan keterbatasan suplai arang tempurung kelapa dan kapasitas mesin produksi (Anita dkk, 2018; Nugroho dkk, 2019). Saat ini BriqCo memiliki kerjasama dengan buyer daerah Timur Tengah yang meminta penyediaan briket sejumlah 2 kontainer per bulan (40 ton). Akan tetapi adanya beberapa keterbatasan pabrik, mengakibatkan BriqCo baru bisa berproduksi sekitar 24 ton per bulan. Oleh karena itu untuk memenuhi permintaan, BriqCo mendirikan satu pabrik lagi yang berfokus pada produksi. Akan tetapi pabrik ini belum dijalankan karena belum tersedianya alat-alat kelengkapan produksi briket. Upaya menindaklanjuti upgrading tersebut, maka pengusul dan mitra menyusun rencana kegiatan pada tahun ketiga, antara lain penyusunan merek dagang Briqco, pengurusan hak paten merek Briqco, pengurusan izin gangguan, penguatan kapasitas UKM seperti relokasi pabrik ke tempat yang lebih memadai, Penguatan branding produk melalui workshop Global Value Chain (GVC), perluasan produksi untuk pemenuhan dalam negeri dari bahan limbah, yaitu bara-bara,ekspansi pada workshop pembuatan mesin produksi, seperti bowler pada oven, dam moulding pada mesin blending untuk bara-bara.

\section{Metode Pelaksanaan}

Saat ini Global Value Chain (GVC) dipandang sebagai metode yang paling tepat untuk menganalisis dan mengarahkan industri kecil dan menengah yang berorientasi ekspor sehingga tidak tergilas oleh globalisasi itu sendiri. UKM yang berorientasi ekspor menjadi bagian dari rantai pertambahan nilai dari pasar global sehingga dapat memberikan kesempatan untuk mendapatkan kesempatan memperoleh keuntungan yang signifikan. Model GVC yang paling sederhana dan mudah adalah dengan cara upgrading. (Kula dkk, 2006)

Upgrading pada tahun ketiga adalah upgrading pada fungsi dan lintas sektoral produk. Hal yang disasar adalah penguatan branding produk dan ekspansi pada mesin-mesin produksi. Penguatan branding produk akan sangat mempengaruhi proses upgrading (Dunn et al, 2006). Jika awalnya, UKM hanya berfungsi membuat briket arang saja maka di tahun ini UKM akan diarahkan untuk menguatkan branding yang sudah dimunculkan di tahun kedua. UKM menjadi tidak tergantung lagi pada buyer namun bisa langsung bertemu dengan konsumen akhir. UKM bisa bermain di dua kaki dimana UKM masih menyediakan briket arang untuk buyer namun disisi lain, UKM juga memiliki merek dagang sendiri yang dijual langsung ke konsumen tingkat akhir. Selain itu upgrading lintas sektoral juga akan menitikberatkan pada pembuatan alat-alat produksi/mesin sendiri. Hal ini tentunya akan menekan cost/biaya produksi. Pembuatan alat-alat ini juga akan menjadi peluang untuk UKM lainnya yang membutuhkan mesin-mesin produksi.

Metode yang dilakukan guna mencapai tujuan tersebut melalui rapat koordinasi, pelatihan dan simulasi, pembuatan alat dengan alih teknologi guna efisiensi produksi, pengurusan legalitas dan paten dan pembuatan website. Implementasi tahun ketiga fokus pada penguatan branding produk, workshop penguatan kapasitas UKM dan ekspansi pada workshop pembuatan mesinmesin produksi.

\section{Hasil dan Pembahasan}

Implementasi PPUD dilakukan sejak bulan Maret sampai dengan Agustus 2020. Pada awal bulan Maret, tim pengusul dan mitra melakukan rapat koordinasi untuk menentukan titik focus implementasi pada tahun ketiga. Pabrik BriqCo sepakat untuk menitikberatkan focus upgrading pada tahun ketiga ini dengan penguatan aspek legalitas, peningkatan branding, dan peningkatan kapasitas produksi briket lokal. BriqCo menyadari bahwa tidak selamanya hanya akan menjadi produsen dibawah branding milik orang lain, seperti yang selama ini dilakukan. Sampai saat ini, BriqCo menjual briket produksinya tanpa menggunakan branding dan setelah itu dikemas oleh agent dan di-packaging dengan brand milik agen tersebut, sehingga nilai keuntungan yang diterima menjadi lebih sedikit. 
Berdasarkan hal tersebut, maka tim PPUD dan mitra bersepakat untuk melakukan implementasi sebagai berikut:

\section{a. Penambahan Kapasitas Produksi Berupa Mesin Cetak dan Blending}

Briqco mulai memanfaatkan limbah produksi briket untuk diolah kembali menjadi barabara, yaitu briket lokal dengan mutu sedang yang digunakan untuk barbeque pada restoranrestoran di Jogjakarta. Bara-bara dibuat dalam bentuk hexagonal, yang memiliki proses sama dengan pembuatan briket kubus, hanya saja diberi moulding berbeda pada mesin blending, Mesin blending dengan moulding hexagonal, dibuat di awal Mei 2020.

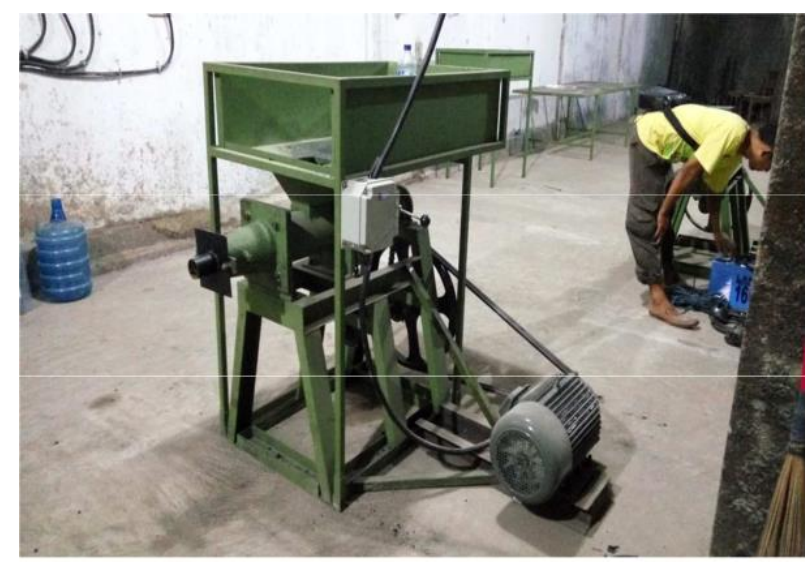

Gambar 1. Mesin blending

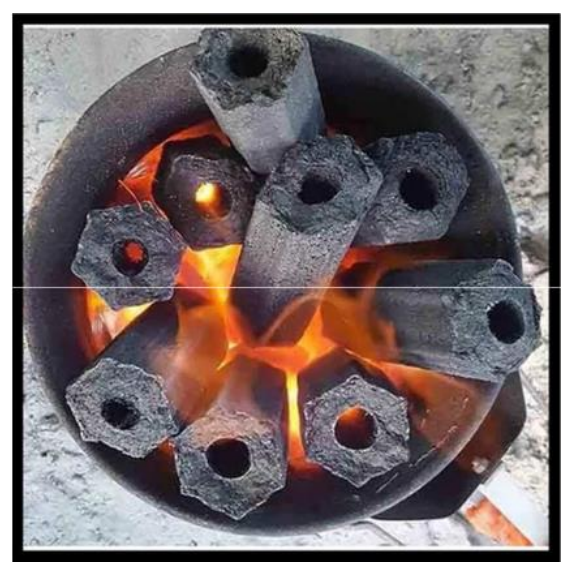

Gambar 2. Bara-bara

\section{b. Pembuatan Aspek Legalitas GV}

Untuk meluncurkan usaha briket arang batok kelapa dengan menggunakan branding sendiri, maka BriqCo harus membuat legalitas terhadap usahanya. Hasil diskusi menyepakati bahwa BriqCo akan membuat CV.Sebuah perusahaan tanpa dasar hukum bisa saja dituntut atau dihentikan usahanya kapan saja. Memiliki badan usaha yang resmi akan membantu untuk mendapatkan proyek-proyek tersebut. Mengerjakan proyek lelang dari swasta dan pemerintah bukan hanya akan mendatangkan keuntungan yang besar, tetapi perusahaan juga akan memiliki rekam bisnis yang baik dan mendapatkan kepercayaan lebih dari konsumen. Memudahkan perusahaan dalam mendapatkan modal tambahan kedepannya. Legalitas usaha bisa membantu Anda untuk mengajukan tambahan modal dari bank, atau mengundang investor dari dalam dan luar negeri. Secara otomatis, kreditur seperti bank akan lebih percaya untuk memberikan pinjaman jika debitur memiliki badan usaha yang jelas. Kesempatan untuk menjaring pasar asing pada saat mendapatkan investor asing. Dengan menarik investor dari luar negeri, kesempatan perusahaan untuk memasarkan jasa atau produk ke pasar internasional juga akan semakin besar.

Saat ini, proses pendirian CV BriqCo masih di notaris. Dokumen yang dibutuhkan untuk pendirian CV sudah diserahkan ke notaris, yaitu: (1) copy atau scan E-KTP, KK, dan NPWP dengan format terbaru dari pengurus perusahaan (Persero Aktif dan Pasif); (2) copy PBB \& bukti bayar PBB tahun terakhir sesuai domisili perusahaan; (3) copy surat kontrak/sewa kantor atau bukti kepemilikan tempat usaha; (4) surat keterangan domisili dari pengelola gedung/ruko; (5) foto kantor tampak dalam dan luar; (6) kantor berada di zonasi perkantoran/zonasi komersial/zonasi campuran. 


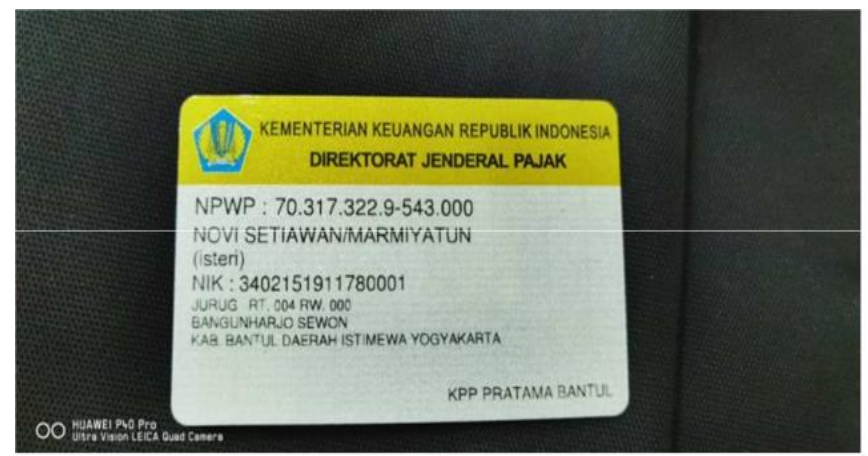

Gambar 3. Terbentuknya kartu NPWP owner
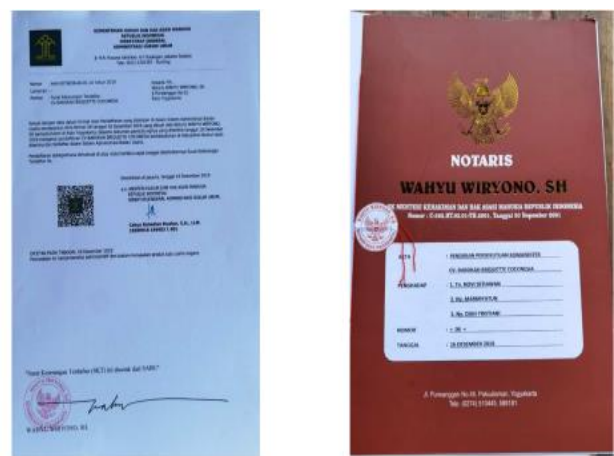

Gambar 4. Akta notaris CV

\section{c. Pembuatan Website BriqCo}

Salah satu cara untuk mengup-grade UMKM BriqCo adalah dengan membuat website. Tujuan pembuatan website ini adalah untuk menampilkan informasi menyeluruh mengenai produk serta berbagai ragam artikel yang sejalan dengan bisnis usaha briket arang batok kelapa. Perkembangan teknologi yang semakin maju, berupa internet, memungkinkan sebuah informasi bisa diakses dari berbagai penjuru tempat. Dengan tersedianya media website yang bisa diakses semua orang, maka usaha BriqCo akan dikenal secara luas. Beberapa keuntungan yang bisa diperoleh dengan pembuatan website usaha adalah sebagai berikut: (1) menjual produk akan terasa lebih mudah dibanding menggunakan media menjualan lain; (2) fitur yang terdapat pada website akan mempermudah komunikasi seller dengan pelanggan; (3) memperoleh jumlah pelanggan yang lebih banyak; (4) dapat membangun branding yang lebih mudah melalui website; (5) perusahaan akan terlihat lebih professional jika memiliki website; dan (6) lebih mudah menemukan partner lain untuk membangun usaha (Dewi \& Darma, 2014). Secara garis besar, keuntungan pembuatan website dapat dilihat pada gambar 5.

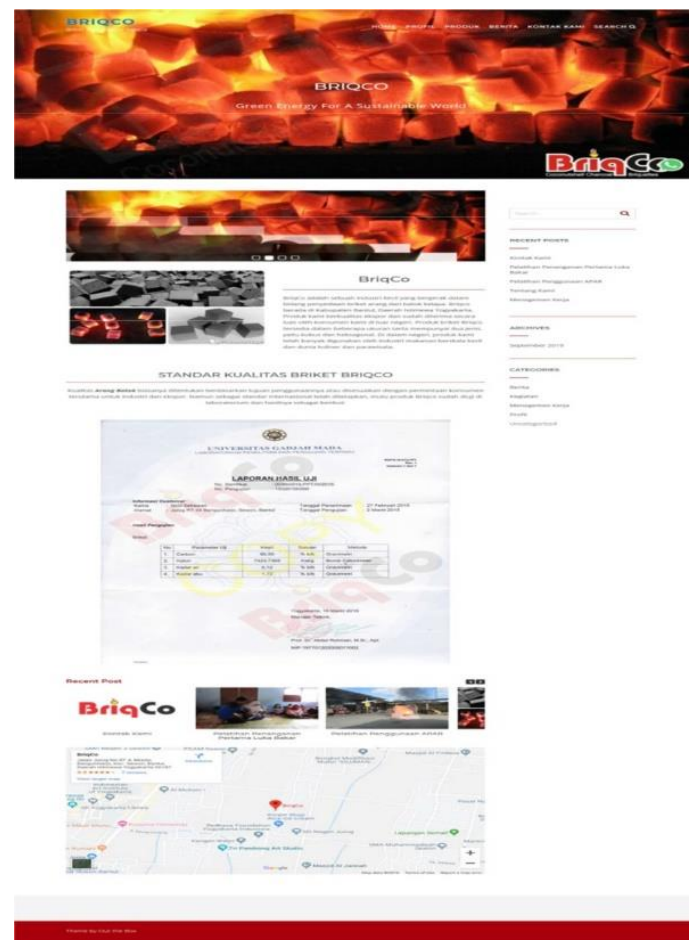

Gambar 5. Tampilan Website 
Alamat url website BriqCo saat ini adalah: www.briqco.id. Menu dalam website terdiri dari: profil perusahaan, produk yang dihasilkan, berita-berita terkait perusahaan, dan menu kontak apabila ada pesanan online. Supaya mendapatkan impact yang optimal dari website, maka yang lebih penting adalah melakukan perawatan (maintenance) website secara professional, supaya: (1)website dapat tampil dalam hasil pencarian pertama di google; (2) pelanggan ingin mendapat respon cepat dari pengelola; (3) user ingin mendapat informasi up to date dari website; (4) kebutuhan industry untuk merubah tampilan/fungsi website dengan cepat; (5) serangan virus dan hacker terhadap website meningkat; (6) hosting membutuhkan perawatan; (7) back up berkala dari website (Dewi \& Darma, 2014).

\section{d. Subsidi Sembako Untuk Karyawan}

Kegiatan ini pada walnya tidak menjadi tujuan kegiatan pengabdian pada tahun ketiga. Namun adanya pandemi, dan menurunnya demand terhadap briket arang tempurung kelapa, serta menurunnya produksi, menyebabkan income 43 karyawan mengalami penurunan. Oleh karena itu, tim pengusul kemudian memberikan subsidi sembako kepada 43 karyawan senilai @300.000. Kegiatan dilaksanakan pada tanggal 7 Juli 2020.
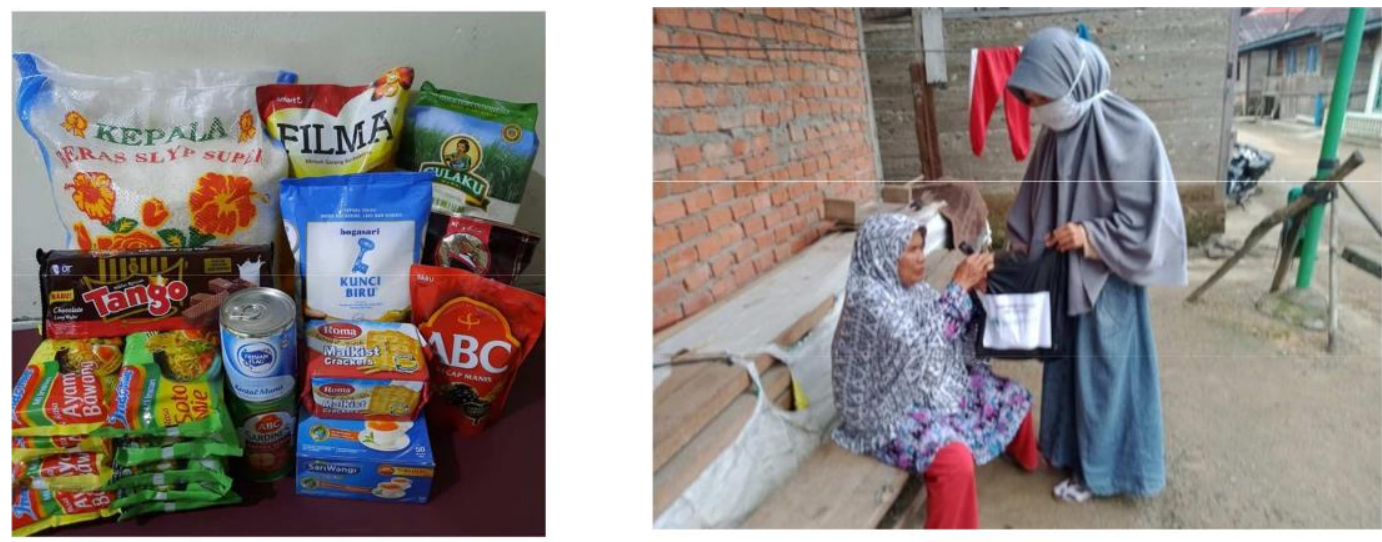

Gambar 6. Pemberian paket sembako untuk karyawan

\section{e. Persiapan Relokasi Pabrik}

Guna meningkatkan produktivitas, mitra dan tim pengusul sepakat untuk memindahkan lokasi Briqco ke daerah dengan sewa tanah yang lebih murah dan lebih luas di Kepek, Sewon, Bantul yang merupakan tanah kas desa. Biaya sewa di daerah tersebut relatif murah, yaitu 50.000 per meter. Hanya saja masih berupa lahan kosong dengan alas semenan. Luas tanah selebar 3000 meter persegi.
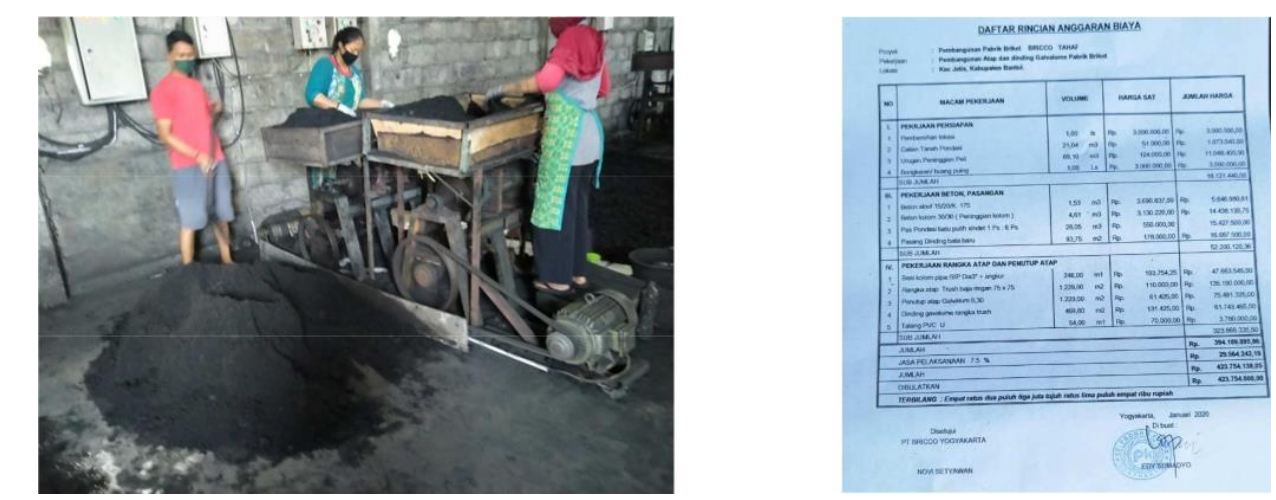

Gambar 7. Pabrik lama yang luasnya 1000 Gambar 8. Rancangan Anggaran Belanja meter persegi

(RAB) relokasi pabrik 
Dampak yang dirasakan pada pelaksanaan PPUD tahun ketiga adalah mitra telah memiliki pabrik milik sendiri yang legal, karena telah mengantongi akta notaris, dan sedang dalam tahap pengurusan izin gangguan, owner menjadi lebih paham akan pentingnya pajak dan kemudian mulai membuat NPWP untuk kepemilikan bersama yaitu suami dan istri, secara branding awareness, owner lebih memiliki pengetahuan dan berusaha untuk meningkatkan produksi setelah relokasi pabrik berhasil dilaksanakan, adanya maintaining website $\mathrm{CV}$ secara berkala, belum terjadi peningkatan income dari bara-bara, karena pendapatkan melalui briket arang kubus menurun akibat bahan baku yang sulit, Tersedianya teknologi tepat guna berupa moulding mesin blending cetak heksagonal. Kontribusi mitra terhadap pelaksanaan pengabdian, antara lain mitra melakukan pengurusan aspek legalitas secara mandiri dengan dibantu pencarian notaris dan pengurusan pajak oleh tim pengusul, mitra berusaha meningkatkan dan mengembangkan website CV secara mandiri, mitra bersama pengusul menemukan pelaksanaan teknologi tepat guna berupa moulding heksagonal pada mesin blending dan cetak.

Faktor utama yang menghambat produksi pada kegiatan PPUD tahun ketiga adalah penurunan pada ketersediaan bahan baku batok kelapa. Selama ini batok kelapa diperoleh sebagian besar dari wilayah Sumatera. Akibat adanya pandemi covid-19, beberapa usaha pengepul batok kelapa mengalami dampak pandemi, dan menurunkan jumlah karyawan. Usaha pengepul batok kelapa di Sumatra sebagian besar mengalami gulung tikar, sehingga menyebabkan adanya pelanggaran kegiatan ekspor berupa biji kelapa utuh ke luar negeri. Akibatnya, penurunan bahan baku batok kelapa yang kemudian berdampak pada penurunan produksi briket. Akibat lain dari ketidaktersediaan bahan baku juga mengakibatkan harga bahan baku mengalami kenaikan 14\%. Sementara itu, harga jual untuk ekspor tidak bisa dinaikkan karena sudah terikat kontrak atara owner dengan buyer tetapnya di Timur Tengah. Kondisi tersebutlah yang justru mengakibatkan income pabrik menjadi menurun. Faktor yang mendukung kegiatan PPUD tahun ketiga adalah Pihak Kepala Dusun yang sangat membantu untuk proses relokasi pabrik setelah pada tahun kedua pabrik mengalami kebakaran, dan pihak mitra yang sadar mengenai wajib pajak dan kepemilikan legalitas perusahaan sehingga bersedia secara mandiri untuk pengurusan NPWP, akta notaris, dan NIB serta HO atau izin gangguan. Untuk mengatasi beberapa permasalahan bahan baku, maka owner kemudian akan berusaha mencari pemasok bahan baku lain, yaitu yang berasal dari Karanganyar. Hanya saja kendalanya, bahan baku di Karanganyar tidak sebanyak ketersediaan bahan baku dari Sumatera, selain itu harga batok kelapanya lebih mahal $24 \%$.

\section{Simpulan}

Simpulan dalam pelaksanaan Program Pengabdian Pengembangan Produk Unggulan Daerah ini adalah Pabrik BriqCo sepakat untuk menitikberatkan focus upgrading dengan penguatan aspek legalitas, peningkatan branding, dan peningkatan kapasitas produksi briket lokal. Tercapainya efisiensi produksi limbah briket arang batok kelapa sekaligus alih teknologi dengan membuat oven pengeringan dengan penambahan bowler, terbentuknya kesadaran diri tentang pentingnya pajak dan aspek legalitas usaha BriqCo, peningkatan branding usaha melalui pembuatan website perusahaan, telah tersedianya akta notaris perusahaan. Penurunan produksi disebabkan karena penurunan ketersediaaan bahan baku batok kelapa

\section{Daftar Pustaka}

Anita, DC., Wulandari, R., Nugroho, SN. (2018). Peningkatan Daya Saing Briket Arang Batok Kelapa Melalui Pendampingan Manajemen Produksi, Pemasaran, Dan Keuangan Pada Usaha BriqCo Dan Briquettes Di Kabupaten Bantul. 24 (4): 848-852. 
Arfani, RN. (2013). GVC (Global Value Chain) Framework: Perspective \& Practices to Comprehend Local - Global Nexus in Trade Relations. Makalah untuk Short Course Series in International Trade (SCSIT) PSPD (Pusat Studi Perdagangan Dunia). UGM: Yogyakarta.

Dewi, CR., Darma, GS. (2014). Website Usability, Satisfaction, Loyalty Security Perception, TrustAnd Word of Mouth In E-Commerce Bussiness. Jurnal Manajemen Dan Bisnis. 11 (2): $1-30$.

Downing J., Campbell, R. (2014). Briefing paper, The Value Chain Framework. USAID diunduh dari link https://www.maxwell.syr.edu/uploadedFiles/exed/sites/pgppm/Program_Readings/10 21_Abonyi-Value_Chain_Framework.pdf

Dunn, E., Sebstad, J., Batzdorff, L., and Parsons H. (2006). Lessons Learned on MSE Upgrading in Value Chains: A Synthesis Paper. AMAP BDS Knowledge and Practice microREPORT \#71, USAID/G/EGAT/MD. Washington DC: ACDI/VOCA.

Faizun, MM., Basuki, HA., Mulyadi, S. (2014). Analisis Penyerapan Energi Kinetik Pada Berbagai Variasi Kecepatan dan Inersia Flywheel. Jurnal Rekayasa Mesin. 5(3): 271274.

Gereffi, G., Fernandez-Stark, K. (2016). Global Value Chain Analysis: A Primer. The Duke Center on Globalization, Governance \& Competitiveness (Duke CGGC) at the Social Science Research Institute, Duke University, North Carolina.

Kula, Olaf, Downing, J., Field, M. (2006). Globalization and the small firm: A value chain approach and poverty reduction. AMAP BDS Knowledge and Practice micro REPORT \#42, USAID/G/EGAT/MD. Washington, D.C: ACDI/VOCA

Nugroho, SN., Anita, DC., Wulandari, R. (2019). Peningkatan Kapasitas Produksi: Pembuatan Belt Conveyor Dan Oven Permanen Pada Upgrading Briket Arang Batok Kelapa. Jurnal Abdimas Unmer Malang. 4(1): 37-40.

Stephenson, S. (2013). Global Value Chains, The New Reality of International Trade, in Global Value Chains: Development Challenges and Policy Options, Proposal and Analysis. From the E15 initiative Strengthening The Global Trade System, E15 Expert Group on Global Value Chains: Development Challenges and Policy Option, Compilation report, Inter-American Development Bank \& International Centre for Trade and Suistainable Development, Genewa, Switzerland. 